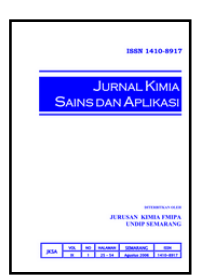

\title{
Kajian Metode Elektrofotokatalisis, Elektrolisis dan Fotokatalisis pada Dekolorisasi Larutan Zat Warna Remazol Brilliant Orange $3 R$ yang Mengandung Ion Logam $\mathrm{Cu}^{2+}$
}

\author{
Arthias Cita Febriyani ${ }^{\mathrm{a}}$, Rum Hastuti ${ }^{\mathrm{a}^{*}}$, Abdul Haris ${ }^{\mathrm{a}}$ \\ a Analytical Chemistry Laboratory, Chemistry Department, Faculty of Sciences and Mathematics, Diponegoro University, Jalan Prof. \\ Soedarto, Tembalang, Semarang \\ * Corresponding author: rum.hastuti@live.undip.ac.id
}

\begin{tabular}{l} 
Article Info \\
\hline \\
\hline Keywords: \\
electrophotocatalysis, \\
electrolysis, \\
photocatalysis, \\
remazol brilliant \\
orange $3 \mathrm{R}, \mathrm{Cu}^{2+}$ ions
\end{tabular}

Kata kunci: elektrofotokatalisis, elektrolisis, fotokatalisis, remazol brilliant orange $3 R$, ion logam $\mathrm{Cu}^{2+}$

\begin{abstract}
Textile industry wastewater contains dyes and heavy metals. Remazol brilliant orange 3R and copper metal are often found in textile wastewater. Disposal of liquid waste textile waste without prior treatment causes pollution on aquatic environments. Electrolysis, photocatalysis and electrophotocatalysis are methods that can be used to treat the textile wastewater. In this study, the three methods were compared to measure the decolourization of a remazol brilliant orange $3 \mathrm{R}$ dye solution containing $\mathrm{Cu}^{2+}$ metal ions as well as to know the effect of $\mathrm{Cu}^{2+}$ metal ions and $\mathrm{UV}-\mathrm{C}$ light irradiation on the decolorization of Remazol brilliant orange $3 \mathrm{R}$ dye. The results showed that electrophotographic method was the most effective method because it was able to decolorize Remazol brilliant orange $3 \mathrm{R}$ to $98.43 \%$ and decrease the concentration of $\mathrm{Cu}^{2+}$ metal ion up to $99.35 \%$. The presence of $\mathrm{Cu}^{2+}$ metal ions and UV$\mathrm{C}$ irradiation increases the decolourization of Remazol brilliant orange $3 \mathrm{R}$ dyes.

\section{Abstrak}

Limbah cair industri tekstil mengandung zat warna dan logam berat. Remazol brilliant orange $3 R$ dan logam tembaga merupakan zat warna dan logam berat yang banyak terdapat pada limbah tekstil. Pembuangan limbah cair tekstil tanpa pengolahan limbah terlebih dahulu akan menyebabkan pencemaran lingkungan perairan. Metode elektrolisis, fotokatalisis dan elektrofotokatalisis merupakan metode yang dapat digunakan dalam penanganan limbah tekstil. Pada penelitian ini akan dibandingkan ketiga metode tersebut untuk dekolorisasi larutan zat warna remazol brilliant orange $3 R$ yang mengandung ion logam $\mathrm{Cu}^{2+}$ serta mengetahui pengaruh keberadaan ion logam $\mathrm{Cu}^{2+}$ dan penyinaran lampu $U V-C$ terhadap dekolorisasi zat warna remazol brilliant orange $3 R$. Hasil penelitian menunjukkan bahwa metode elektrofotokatalisis merupakan metode yang paling efektif karena mampu mendekolorisasi remazol brilliant orange 3R hingga 98,43\% dan menurunkan konsentrasi ion logam $\mathrm{Cu}^{2+}$ hingga 99,35\%. Keberadaan ion logam $\mathrm{Cu}^{2+}$ dan penyinaran lampu $U V-C$ meningkatkan dekolorisasi zat warna remazol brilliant orange $3 R$.
\end{abstract}

\section{Pendahuluan}

Industri tekstil dan produk tekstil merupakan salah satu industri yang sangat berkembang. Industri tekstil menghasilkan limbah cair berwarna yang dapat berpengaruh terhadap estetika, kekeruhan, dan toksisitas pada biota air (ganggang dan ikan). Selain itu, sebagian zat warna tersebut bersifat karsinogenik [1].

Zat warna reaktif merupakan zat warna yang banyak digunakan dalam proses pewarnaan tekstil, misalnya remazol brilliant orange $3 R$, remazol black $B$, remazol golden yellow, dan remazol brilliant blue [2]. Salah 
satu zat warna yang banyak digunakan adalah remazol brilliant orange $3 R$ atau yang biasa dikenal dengan reactive orange 16 [3]. Limbah tekstil selain mengandung sisa zat warna reaktif juga mengandung logam berat. Logam berat sering kali digunakan dalam proses pewarnaan tekstil untuk mengikat dan memperkuat warna. Logam tembaga merupakan logam yang banyak digunakan dalam pewarnaan industri tekstil.

Pengolahan limbah cair dimaksudkan untuk menghilangkan kadar bahan pencemar yang terkandung di dalam limbah cair agar memenuhi syarat untuk dapat dibuang ke lingkungan. Limbah yang dibuang tanpa pengolahan dapat membahayakan bagi kesehatan, seperti iritasi pada kulit dan kanker [4].

Salah satu metode alternatif pengolahan limbah cair zat warna adalah dengan fotokatalisis. Fotokatalisis merupakan kombinasi dari proses fotokimia dan katalis yang terintegrasi untuk dapat melangsungkan suatu reaksi transformasi kimia [5]. Metode lain yang dapat digunakan untuk menghilangkan zat warna adalah dengan elektrolisis. Metode elektrofotokatalisis merupakan penggabungan dari dua metode yaitu metode elektrolisis dan fotokatalisis yang banyak dikembangkan untuk proses pengolahan limbah.

Penelitian ini bertujuan untuk mengkaji metode elektrofotokatalisis, elektrolisis, dan fotokatalisis pada dekolorisasi larutan zat warna remazol brilliant orange $3 R$ yang mengandung ion logam $\mathrm{Cu}^{2+}$ serta mengetahui pengaruh ion logam $\mathrm{Cu}^{2+}$ dan penyinaran lampu $U V-C$ pada dekolorisasi zat warna remazol brilliant orange $3 R$.

\section{Metode Penelitian}

\section{Alat dan Bahan}

Peralatan yang mendukung penelitian ini adalah elektroanaliser, reaktor fotokatalis, lampu UV-C, peralatan gelas, magnetik stirrer, spektrometer $U V$-Vis shimadzu dan spektrometer UV-Vis tipe T60U, serta Atomic Absorption Spectrophotometry (AAS).

Bahan yang digunakan dalam penelitian ini meliputi Zat warna remazol brilliant orange $3 R$, $\mathrm{CuSO}_{4} \cdot 5 \mathrm{H}_{2} \mathrm{O}$ p.a, $\mathrm{TiO}_{2}$ p.a, $\mathrm{Na}_{2} \mathrm{SO}_{4}$ p.a, batang karbon, akuades, serta aseton.

\section{Prosedur Penelitian}

Larutan sampel yang merupakan campuran zat warna remazol brilliant orange $3 \mathrm{R}$ dan ion logam $\mathrm{Cu}^{2+}$ ditentukan panjang gelombang maksimumnya menggunakan spektrofotometer UV-Vis. Kemudian dilakukan penentuan potensial kerja untuk proses elektrofotokatalisis dan fotokatalisis, serta dilakukan penentuan waktu optimum yang akan digunakan untuk proses elektrofotokatalisis, elektrolisis, maupun fotokatalisis.

Prosedur elektrofotokatalisis dilakukan di dalam reaktor fotokatalis yang dilengkapi sel elektrokimia dengan elektroda karbon. Larutan sampel sebanyak 100 mL ditambah 1,4 gram $\mathrm{Na}_{2} \mathrm{SO}_{4}$ dan 0,05 gram serbuk $\mathrm{TiO}_{2}$ sambil dilakukan pengadukan dengan magnetik stirer.
Prosedur elektrolisis dilakukan di dalam sel elektrokimia dengan elektroda karbon. Larutan sampel sebanyak $100 \mathrm{~mL}$ ditambah 1,42 gram $\mathrm{Na}_{2} \mathrm{SO}_{4}$ kemudian dilakukan proses elektrolisis.

Prosedur fotokatalisis dilakukan di dalam reaktor fotokatalis. Larutan sampel $100 \mathrm{~mL}$ ditambah dengan serbuk fotokatalis $\mathrm{TiO}_{2}$ sebanyak 0,05 gram sambil dilakukan pengadukan dengan magnetik stirer, kemudian diletakkan dalam reaktor fotokatalis dan dilakukan penyinaran dengan lampu UV-C.

Untuk mengetahui pengaruh ion logam $\mathrm{Cu}^{2+}$ dan penyinaran dengan lampu UV-C dilakuakn proses elektrofotokatalisis, elektrolisis, dan fotokatalisis dengan dan tanpa adanya ion logam $\mathrm{Cu}^{2+}$ dan penyinaran dengan lampu UV-C.

Analisis kualitatif meliputi pengamatan warna larutan sampel. Analisis kuantitatif meliputi penentuan nilai absorbansi larutan sampel menggunakan spektrofotometer UV-Vis dan analisis kandungan ion logam $\mathrm{Cu}^{2+}$ menggunakan Atomic Absorption Spectrophotometry (AAS).

\section{Hasil Dan Pembahasan}

Penentuan Panjang Gelombang Maksimum

Pengukuran panjang gelombang maksimum zat warna remazol brilliant orange $3 R$ dilakukan sebelum dan sesudah larutan zat warna remazol brilliant orange $3 R$ dicampur dengan ion logam $\mathrm{Cu}^{2+}$.

Spektra UV-Vis remazol brilliant orange $3 R$ seperti disajikan gambar 1 menunjukkan suatu bentuk kurva yang spesifik yang dipengaruhi oleh adanya gugus kromofor dalam senyawa tersebut. Pada kurva terlihat puncak serapan pada $254 \mathrm{~nm}$ yang merupakan karakteristik benzena. Puncak serapan pada $297 \mathrm{~nm}$ dan $388 \mathrm{~nm}$ merupakan benzena yang terkonjugasi [6], sedangkan puncak pada $494 \mathrm{~nm}$ mengidentifikasikan karakter warna senyawa tersebut. Pada gambar 2 menunjukkan bahwa tidak ada pergeseran apabila larutan remazol brilliant orange $3 R$ dicampur dengan ion logam $\mathrm{Cu}^{2+}$. Keberadaan $\mathrm{Cu}^{2+}$ tidak mempengaruhi puncak spektra UV-Vis remazol brilliant orange $3 R$ yang menunjukkan $\mathrm{Cu}^{2+}$ tidak berinteraksi kimiawi dengan zat warna remazol brilliant orange $3 R$.

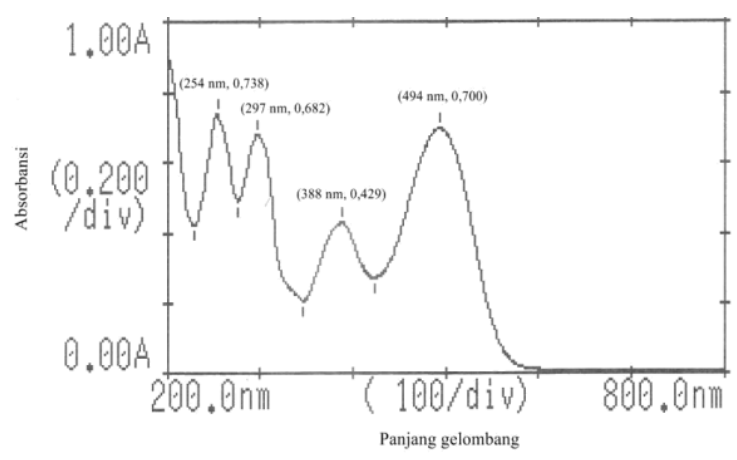

Gambar 1. Spektra UV-Vis remazol brilliant orange 3R 


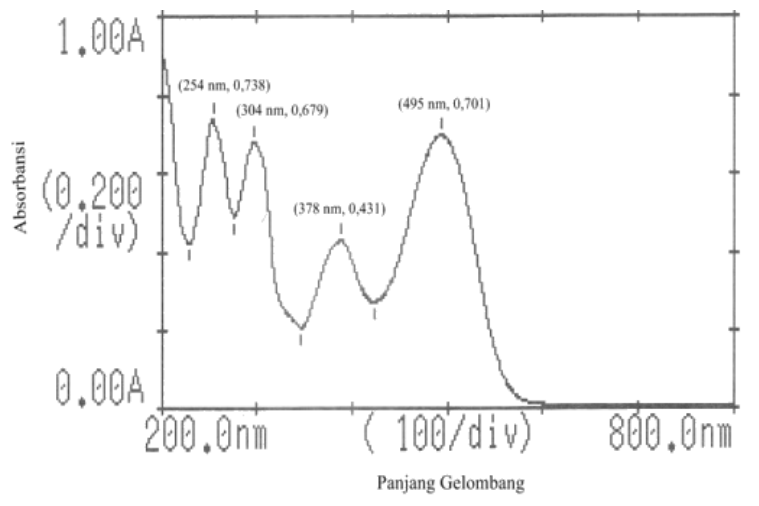

Gambar 2. Spektra UV-Vis campuran remazol brilliant orange $3 \mathrm{R}$ dan ion logam $\mathrm{Cu}^{2+}$

\section{Penenruan Potensial Kerja}

Gambar 3 memberikan informasi tentang rentang potensial elektrofotokatalisis untuk proses elektrofotokatalisis selanjutnya, rentang potensial diperoleh dengan menentukan titik belok kurva. Dari kurva di bawah diperoleh rentang potensial 4,9-5,2 volt yang merupakan rentang potensial antara larutan remazol brilliant orange $3 R$ yang mengandung ion logam $\mathrm{Cu}^{2+}$ sebagai sampel dan akuades sebagai blanko. Selanjutnya, potensial kerja ditetapkan sebesar 5,0 volt dan dijaga konstan selama proses. Untuk proses elektrolisis diperoleh rentang potensial 4,2-5,4 volt seperti ditunjukkan pada gambar 4, selanjutnya potensial kerja ditetapkan 5,2 volt. Elektrofotokatalisis dan elektrolisis dilakukan pada rentang potensial yang telah diperoleh, karena bila dilakukan di luar daerah rentang potensial ini akan mengakibatkan pelarut yang digunakan akan terelektrolisis sehingga terjadi kompetisi antara sampel dan pelarut.

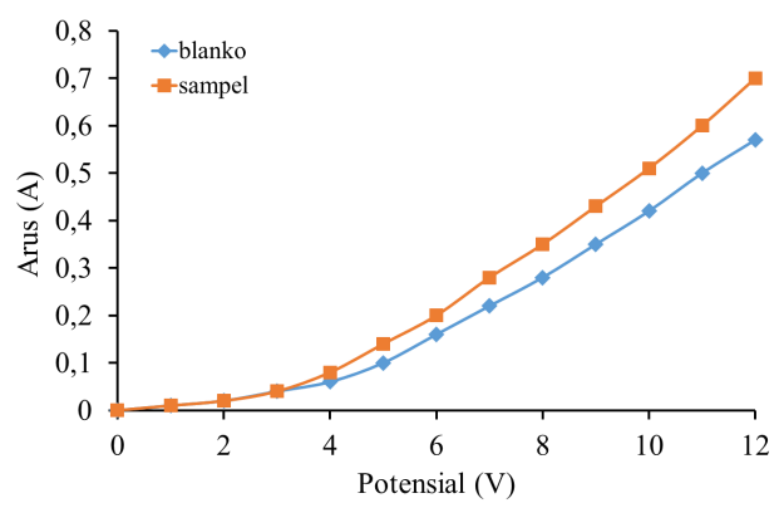

Gambar 3. Kurva hubungan antara arus dan potensial pada elektrofotokatalisis larutan sampel dan blanko dengan elektroda $\mathrm{C} / \mathrm{C}$

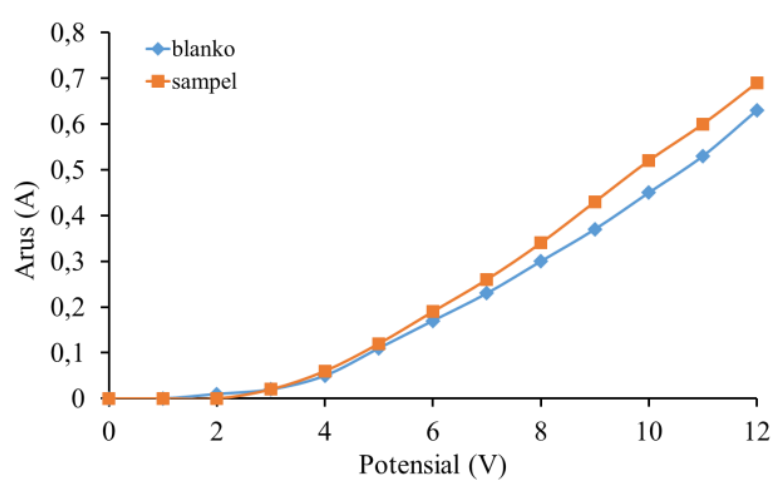

Gambar 4. Kurva hubungan antara arus dan potensial pada elektrolisis larutan sampel dan blanko dengan elektroda $\mathrm{C} / \mathrm{C}$

\section{Penentuan Waktu Optimum}

Elektrofotokatalisis larutan sampel zat warna remazol brilliant orange $3 R$ yang mengandung ion logam $\mathrm{Cu}^{2+}$ dilakukan menggunakan elektroda $\mathrm{C} / \mathrm{C}$ pada potensial 5,0 volt. Pengukuran absorbansi dilakukan setiap 15 menit pada panjang gelombang maksimum $495 \mathrm{~nm}$. Dari data yang didapat kemudian digambarkan sebagai kurva waktu terhadap absorbansi yang ditunjukkan pada gambar 5 .

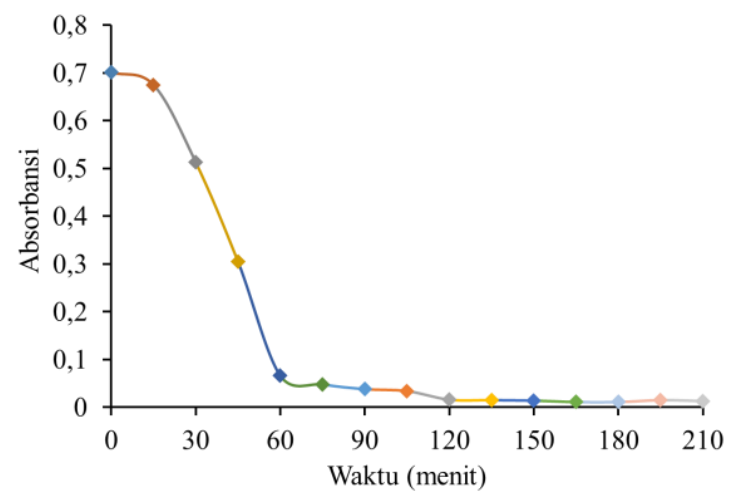

Gambar 5. Kurva absorbansi terhadap waktu pada elektrofotokatalisis larutan sampel dengan elektroda

$\mathrm{C} / \mathrm{C}$, potensial 5,0 volt yang diukur pada $495 \mathrm{~nm}$.

Kurva tersebut memberikan informasi tentang hubungan antara lama waktu elektrofotokatalisis dengan absorbansi sampel, selain itu juga diperoleh informasi tentang waktu minimal dekolorisasi larutan remazol brilliant orange $3 R$ yang mengandung ion logam $\mathrm{Cu}^{2+}$. Waktu optimum selanjutnya ditetapkan 180 menit untuk proses elektrofotokatalisis, elektrolisis, dan fotokatalisis.

\section{Elektrofotokatalisis Larutan Sampel}

Elektrofotokatalisis larutan sampel zat warna remazol brilliant orange $3 R$ yang mengandung ion logam $\mathrm{Cu}^{2+}$ dilakukan menggunakan elektroda $\mathrm{C} / \mathrm{C}$ dengan waktu elektrofotokatalisis 180 menit dan potensial sebesar 5,0 volt serta ditambahkan 0,05 gram serbuk $\mathrm{TiO}_{2}$. Proses elektrofotokatalisis dilakukan di dalam reaktor fotokatalis yang dilengkapi lampu $U V-C$.

Setelah proses elektrofotokatalisis, terjadi penurunan intensitas dan perubahan warna. Warna 
yang semula berwarna orange pekat berubah menjadi tidak berwarna. Penurunan intensitas warna setelah proses elektrofotokatalisis disebabkan oleh proses perusakan struktur substrat zat warna karena pengaruh elektrofotokatalisis. Perusakan berlangsung melalui reaksi oksidasi di anoda dan dikontribusi oleh adanya $\mathrm{TiO}_{2}$ sebagai fotokatalis. Produk oksidasi di anoda diperkirakan berupa $\mathrm{H}_{2} \mathrm{O}$ dan $\mathrm{CO}_{2}$ serta senyawa rantai karbon pendek yang tidak lagi menyerap radiasi pada panjang gelombang visible. Kontribusi terhadap dekolorisasi dari penambahan $\mathrm{TiO}_{2}$ sebagai fotokatalis dapat dijelaskan sebagai berikut [7].

$$
\begin{aligned}
& \mathrm{TiO}_{2}+h v \rightarrow \mathrm{TiO}_{2}\left(h^{+}+\mathrm{e}^{-}\right) \\
& \mathrm{H}_{2} \mathrm{O}+h^{+} \rightarrow \mathrm{H}^{+}+{ }^{-} \mathrm{OH} \\
& \mathrm{OH}^{-}+h^{+} \rightarrow-{ }^{-} \mathrm{OH}
\end{aligned}
$$

Menurut Attia dkk. [8] -OH akan menginisiasi degradasi pada gugus utama senyawa azo yang kemudian akan menjadi $\mathrm{CO}_{2}$ dan $\mathrm{H}_{2} \mathrm{O}$.

Hasil analisis spektra UV-Vis terhadap larutan sampel setelah elektrofotokatalisis seperti disajikan pada gambar 6 menunjukkan tidak terlihat puncak serapan pada $304 \mathrm{~nm}$ dan $378 \mathrm{~nm}$ yang merupakan puncak dari gugus benzena terkonjugasi serta puncak pada $495 \mathrm{~nm}$ yang merupakan puncak dari gugus kromofor, hal ini menandakan zat warna telah terdegradasi.

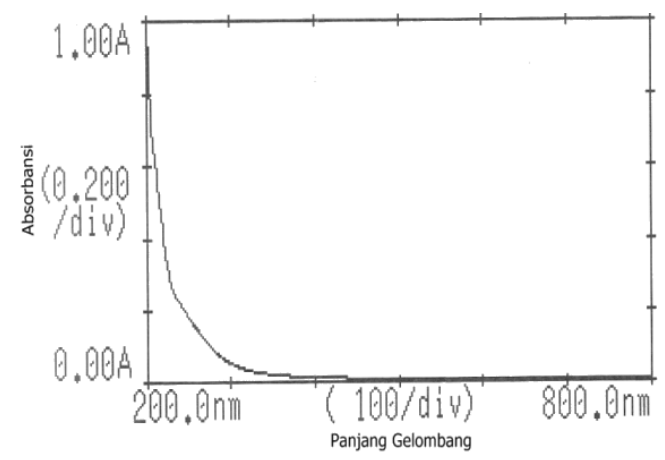

Gambar 6. Spektra UV-Vis remazol brilliant orange $3 R$ setelah elektrofotokatalisis

\section{Elektrolisis Larutan Sampel}

Elektrolisis dilakukan menggunakan elektroda C/C dengan waktu elektrolisis 180 menit dan potensial sebesar 5,2 volt. Setelah proses elektrolisis, terjadi penurunan intensitas dan perubahan warna. Warna yang semula berwarna orange pekat berubah menjadi orange jernih. Penurunan intensitas warna setelah proses elektrolisis disebabkan oleh proses perusakan struktur substrat zat warna karena pengaruh elektrolisis.

Hasil analisis spektra UV-Vis terhadap larutan sampel setelah elektrolisis seperti disajikan pada gambar 7 menunjukkan masih terlihat puncak serapan pada $495 \mathrm{~nm}$ yang merupakan puncak dari gugus kromofor, hal ini menandakan zat warna belum terdegradasi sempurna.

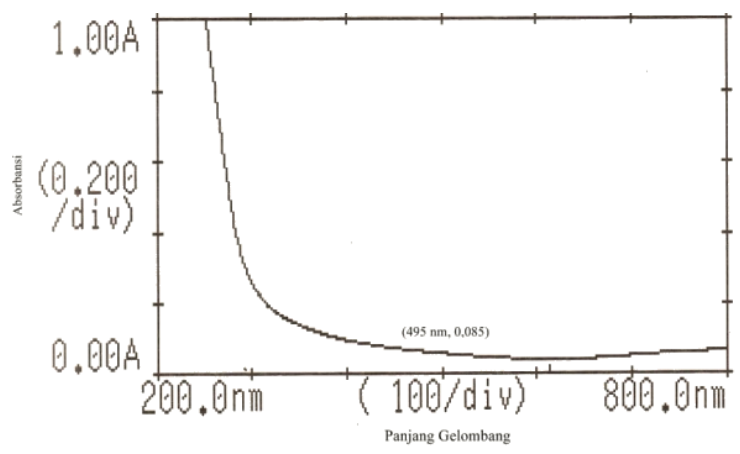

Gambar 7. Spektra UV-Vis remazol brilliant orange $3 R$ setelah elektrolisis

\section{Fotokatalisis Larutan Sampel}

Fotokatalisis dilakukan dengan penambahan serbuk $\mathrm{TiO}_{2}$ serta dilakukan di dalam reaktor fotokatalis ynag dilengkapi lampu UV-C selama 180 menit sambil dilakukan pengadukan. Lampu UV-C berfungsi sebagai sumber energi foton $(h v)$ supaya reaksi fotokatalisis dapat berlangsung. Pengadukan yang dilakukan bertujuan agar semua reaktan dalam sistem reaksi dapat bercampur merata sehingga diharapkan proses fotokatalisis dapat berjalan efektif.

Mekanisme fotokatalis $\mathrm{TiO}_{2}$ dapat dijelaskan secara bertahap yaitu mekanisme yang melibatkan eksitasi fotokatalis $\mathrm{TiO}_{2}$ ketika dikenai cahaya dengan panjang gelombang sekitar $380 \mathrm{~nm}$ [9].

$$
\begin{aligned}
& \mathrm{TiO}_{2}+\mathrm{hv} \rightarrow \mathrm{TiO}_{2}\left(\mathrm{~h}_{\mathrm{vb}}{ }^{+}+\mathrm{e}_{\mathrm{cb}}{ }^{-}\right) \\
& \mathrm{h}^{+}+\mathrm{H}_{2} \mathrm{O} \rightarrow-\mathrm{OH}+{ }^{-} \mathrm{H} \\
& \mathrm{h}^{+}+{ }^{-} \mathrm{OH} \rightarrow-{ }^{-} \mathrm{OH}
\end{aligned}
$$

-OH akan menyerang gugus azo yang merupakan kromofor dari zat warna sehingga zat warna akan terdegradasi menjadi $\mathrm{CO}_{2}$ dan $\mathrm{H}_{2} \mathrm{O}$.

Dari gambar 8 dapat dilihat bahwa dalam waktu 180 menit, metode fotokatalisis belum sempurna terdegradasi zat warna remazol brilliant orange $3 R$, pada spektra $U V$-Vis masih terlihat adanya gugus kromofor pada panjang gelombang $495 \mathrm{~nm}$ dan benzena terkonjugasi pada panjang gelombang $373 \mathrm{~nm}$ yang belum sempurna teroksidasi oleh $\mathrm{TiO}_{2}$. Dalam waktu 180 menit fotokatalisis ini hanya mampu menurunkan absorbansi sebesar $38,23 \%$. Hal ini disebabkan kurang lamanya waktu fotokatalisis sehingga proses yang terjadi di dalamnya kurang sempurna.

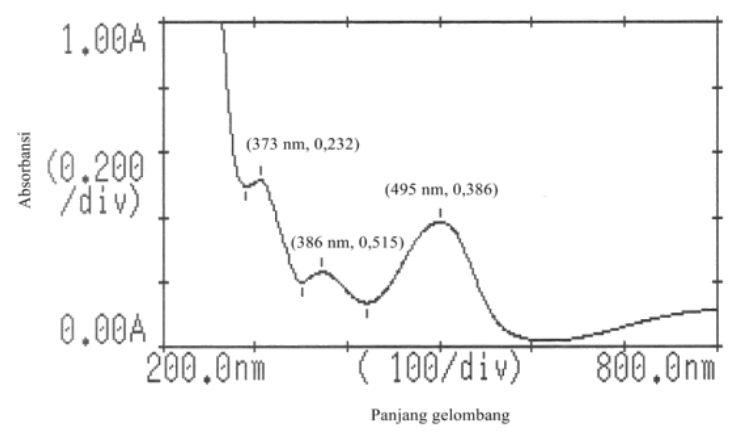

Gambar 8. Spektra UV-Vis remazol brilliant orange $3 R$ setelah fotokatalisis 
Perbandingan Metode Elektrofotokatalisis, Elektrolisis, dan Fotokatalisis

Untuk mengetahui metode yang paling efektif dalam proses dekolorisasi larutan sampel adalah dengan membandingkan ketiga metode yaitu elektrofotokatalisis, elektrolisis, dan fotokatalisis pada kondisi yang sama. Elektrofotokatalisisis, elektrolisis, dan fotokatalisis dilakukan dengan waktu yang sama yaitu selama 180 menit. Setelah 180 menit, absorbansi larutan diukur dengan spektrofotometer UV-Vis dan konsentrasi ion logam $\mathrm{Cu}^{2+}$ dengan Atomic Absoption Spectrophotometry (AAS).

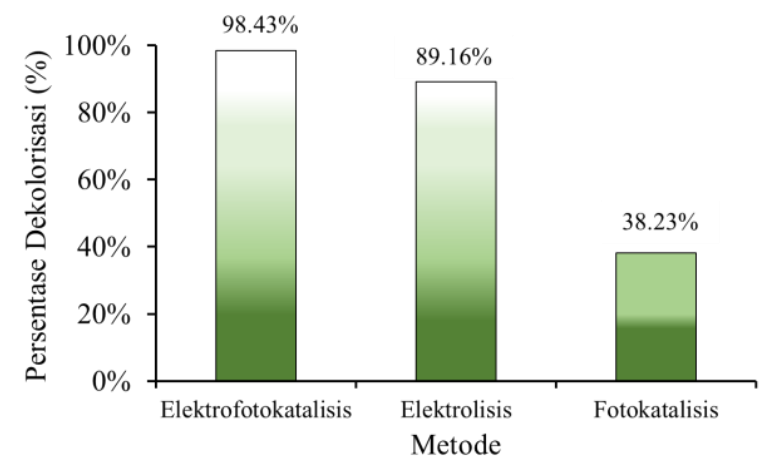

Gambar 9. Plot hubungan antara besar persentase dekolorisasi larutan sampel dengan metode yang digunakan

Grafik pada gambar 9 menunjukkan persentase dekolorisasi dari ketiga metode. Dari ketiga metode tersebut metode elektrofotokatalisis merupakan metode terbaik yaitu mampu mendekolorisasi larutan zat warna remazol brilliant orange hingga 98,43\%.

Gambar 10 menunjukkan bahwa dengan metode elektrofotokatalisis merupakan metode paling efektif dibandingkan metode fotokatalisis dan metode elektrolisis dalam menurunkan konsentrasi logam karena mampu menurunkan konsentrasi ion logam $\mathrm{Cu}^{2+}$ hingga 99,35\% sedangkan dengan metode fotokatalisis hanya mampu menurunkan konsentrasi logam sebesar 4\% dan metode elektrolisis hanya mampu menurunkan konsentrasi logam sebesar 50,83\%. Hal ini disebabkan pada proses elektrofotokatalisis berlangsung dua proses sekaligus yaitu proses fotokatalisis dan proses elektrolisis. Pada proses elektrolisis terjadi proses reduksi ion logam $\mathrm{Cu}^{2+}$ menjadi $\mathrm{Cu}$ yang mengendap di anoda dan pada proses fotokatalisis terjadi fotoreduksi pada permukaan $\mathrm{TiO}_{2}$ sehingga konsentrasi logam menurun. Reaksi reduksi ion logam $\mathrm{Cu}^{2+}$ menjadi $\mathrm{Cu}$ adalah sebagai berikut.

$$
\begin{aligned}
& \mathrm{Cu}^{2+}(\mathrm{aq})+2 \mathrm{e}-\rightarrow \mathrm{Cu}(\mathrm{s}) \\
& \mathrm{E}_{0}=0,34 \text { Volt }
\end{aligned}
$$

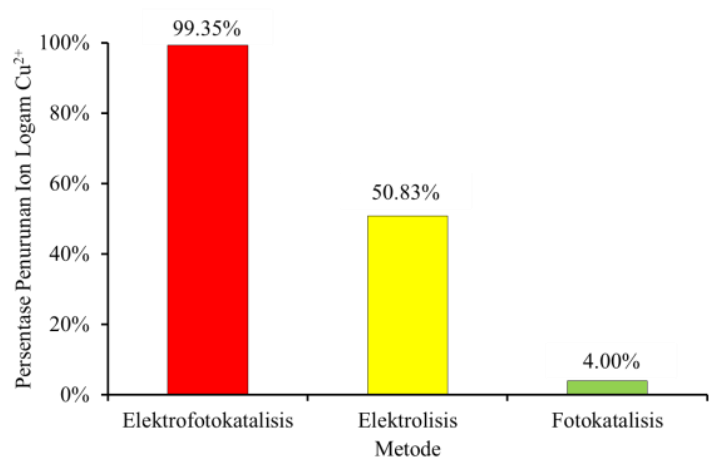

Gambar 10. Plot hubungan antara besar persentase penurunan ion logam $\mathrm{Cu}^{2+}$ larutan sampel dengan metode yang digunakan dengan konsentrasi awal ion $\operatorname{logam~} \mathrm{Cu}^{2+} 600 \mathrm{ppm}$

\section{Pengaruh Ion Logam $\mathrm{Cu}^{2+}$ dan Penyinaran dengan Lampu UV-C}

Untuk mengetahui pengaruh ion $\mathrm{Cu}^{2+}$ terhadap efektifitas dekolorisasi larutan zat warna remazol brilliant orange $3 \mathrm{R}$, dilakukan dengan membandingkan dekolorisasi larutan zat warna remazol brilliant orange $3 \mathrm{R}$ tanpa dan dengan penambahan ion $\mathrm{Cu}^{2+}$ sebesar 600 ppm.

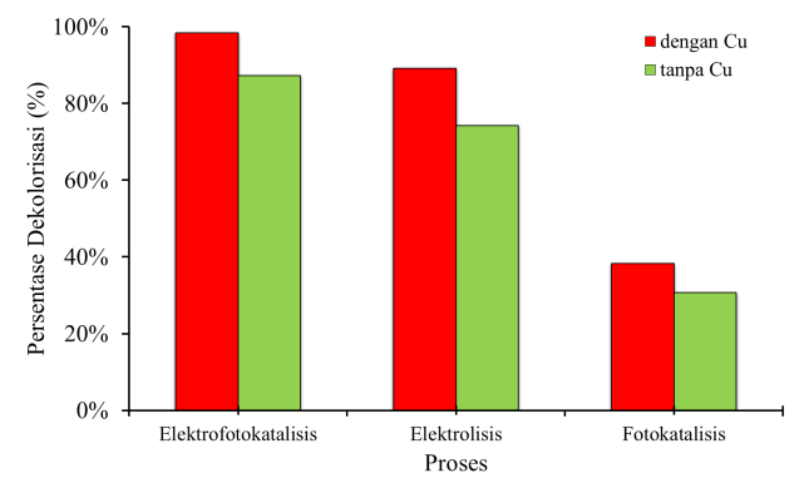

Gambar 11. Kurva persentase perbandingan efektifitas dekolorisasi remazol brilliant orange $3 \mathrm{R}$ menggunakan proses elektrofotokatalisis, fotokatalis dan elektrolisis dengan dan tanpa adanya ion logam $\mathrm{Cu}^{2+}$

Gambar 11 menunjukkan bahwa dengan adanya ion logam $\mathrm{Cu}^{2+}$ akan menaikkan efektifitas dekolorisasi larutan remazol brilliant orange $3 \mathrm{R}$. Hal ini disebabkan pada sistem terkatalisis $\mathrm{TiO}_{2}$ bila dikenai cahaya UV akan menghasilkan elektron dan hole secara terus menerus. Sebagian besar pasangan elektron dan hole ini akan berekombinasi kembali. Dengan adanya penambahan ion logam $\mathrm{Cu}^{2+}$ maka elektron akan menginisiasi reaksi reduksi $\mathrm{Cu}^{2+}$ yang ada di sekitar permukaan semikonduktor sementara hole akan menginisiasi reaksi oksidasi larutan remazol brilliant orange 3R.

Untuk mengetahui pengaruh penyinaran lampu UV-C terhadap efektifitas dekolorisasi larutan zat warna remazol brilliant orange $3 \mathrm{R}$, dilakukan dengan membandingkan efektifitas dekolorisasi larutan zat warna remazol brilliant orange $3 \mathrm{R}$ tanpa dan dengan adanya penyinaran lampu UV-C pada metode elektrofotokatalisis dan fotokatalisis. 


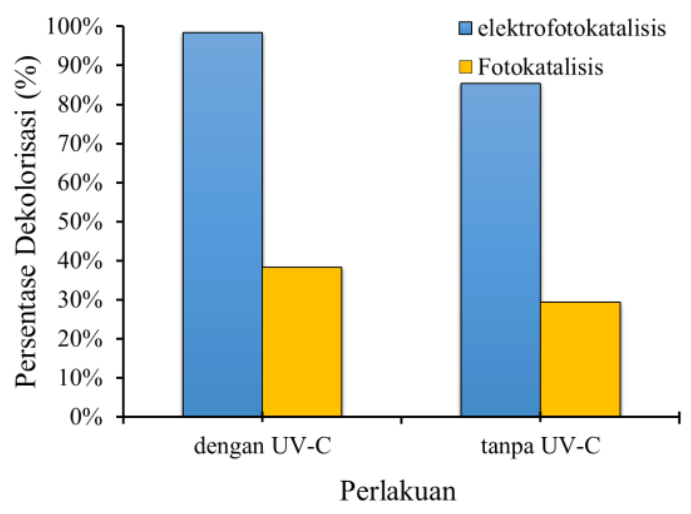

Gambar 12. Kurva persentase perbandingan efektifitas dekolorisasi remazol brillianr orange $3 \mathrm{R}$ menggunakan proses elektrofotokatalisis dan fotokatalisis dengan dan tanpa adanya penyinaran lampu UV-C

Gambar 12 menunjukkan bahwa adanya penyinaran lampu UV-C akan menaikkan efektifitas dekolorisasi larutan remazol brilliant orange 3R dan gambar 13 menunjukkan bahwa adanya penyinaran dengan lampu UV-C akan menaikkan efektifitas penurunan konsentrasi ion logam $\mathrm{Cu}^{2+}$. Adanya UV akan menghasilkan energi sehingga elektron akan tereksitasi yang akan menghasilkan $\cdot \mathrm{OH}$ secara terus-menerus. Pada kondisi gelap terjadi aktivitas adsorpsi pada permukaan sisi aktif $\mathrm{TiO}_{2}$ karena adanya kekosongan pada sisi aktif $\mathrm{TiO}_{2}$. Kekosongan sisi aktif ini kemungkinan akan diisi oleh zat warna remazol brilliant orange $3 \mathrm{R}$ dan ion logam $\mathrm{Cu}^{2+}$.

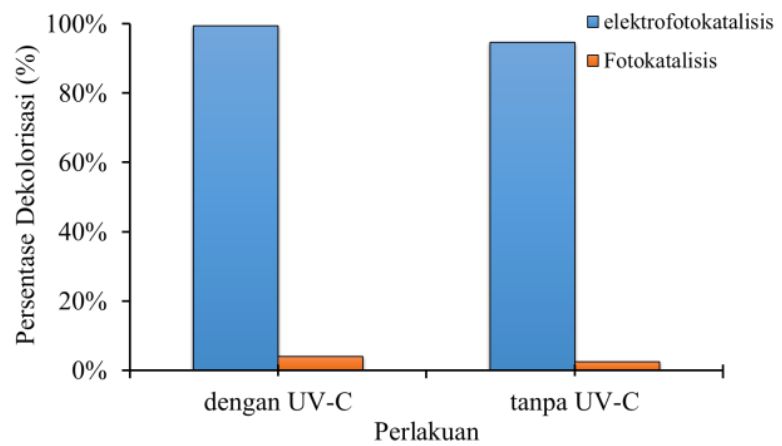

Gambar 13. Kurva persentase perbandingan efektifitas penurunan konsentrasi ion logam $\mathrm{Cu}^{2+}$ menggunakan proses elektrofotokatalisis dan fotokatalis dengan dan tanpa adanya penyinaran lampu UV-C dengan konsentrasi awal ion logam $\mathrm{Cu}^{2+} 600 \mathrm{ppm}$

Dari data diatas dapat diketahui bahwa efektifitas remazol brilliant orange $3 \mathrm{R}$ akan meningkat dengan adanya ion logam $\mathrm{Cu}^{2+}$ yang akan menjaga jumlah elektron dalam sistem reaksi dengan mencegah terjadinya rekombinasi dengan radikal $\mathrm{OH}$ dan dengan adanya penyinaran lampu UV-C sehingga dihasilkan elektron dan hole yang akan berperan sebagai reduktor serta oksidator pada larutan sampel remazol brilliant orange $3 \mathrm{R}$ yang mengandung ion logam $\mathrm{Cu}^{2+}$

\section{Kesimpulan}

Metode elektrofotokatalisis, elektrolisis, dan fotokatalisis mampu mendekolorisasi larutan zat warna remazol brilliant orange $3 \mathrm{R}$ yang mengandung ion logam $\mathrm{Cu}^{2+}$ dan metode elektrofotokatalisis merupakan metode yang paling efektif dalam mendekolorisasi zat warna remazol brilliant orange $3 \mathrm{R}$ serta menurunkan konsentrasi ion logam $\mathrm{Cu}^{2+}$. Persentase dekolorisasi zat warna remazol brilliant orange $3 \mathrm{R}$ dengan metode elektrofotokatalisis, elektrolisis, dan fotokatalisis berturut-turut adalah 98,43\%, 89,16\%, dan 38,23\%, sedangkan persentase penurunan konsentrasi ion logam $\mathrm{Cu}^{2+}$ dengan metode elektrofotokatalisis, elektrolisis, dan fotokatalisis berturut-turut adalah 99,35\%, 50,83\%, dan 4,00\%. Keberadaan ion logam $\mathrm{Cu}^{2+}$ dan penyinaran lampu UV-C meningkatkan dekolorisasi zat warna remazol brilliant orange $3 \mathrm{R}$.

\section{Daftar Pustaka}

[1] Aried Ardhina, Dekolorisasi Limbah Cair Industri Tekstil dengan Menggunakan Omphalina sp, (2007)

[2] M Esteves, Elisabete Sousa, Electrochemical degradation of $\mathrm{CI}$ reactive orange 16 in the presence of $\mathrm{H} 2 \mathrm{O} 2 / \mathrm{Cu}+$ Ions, (2006)

[3] Chih-Yu Chen, Photocatalytic Degradation of Azo Dye Reactive Orange 16 by TiO2, Water, Air, and Soil Pollution, 202, 1, (2009) 335-342 http://dx.doi.org/10.1007/s11270-009-9980-4

[4] MN Rashed, AA El-Amin, Photocatalytic degradation of methyl orange in aqueous $\mathrm{TiO} 2$ under different solar irradiation sources, International Journal of Physical Sciences, 2, 3, (2007) 73-81

[5] Rachmat Triandi Tjahjanto, Jarnuzi Gunlazuardi, Preparasi Lapisan Tipis TiO2 sebagai Fotokatalisis: Keterkaitan antara Ketebalan dan Aktivitas Fotokatalisis, Jurnal Penelitian Universitas Indonesia, 5, 2, (2001) 81-91

[6] Robert M Silverstein, G Clayton Bassler, Terence C Morrill, Spectroscopic identification of organic compounds, Wiley, New York, (1981) 196

[7] Md Ahsan Habib, Iqbal Mohmmad Ibrahim Ismail, Abu Jafar Mahmood, Md Rafique Ullah, Photocatalytic decolorization of Brilliant Golden Yellow in $\mathrm{TiO} 2$ and $\mathrm{ZnO}$ suspensions, Journal of Saudi Chemical Society, 16, 4, (2012) 423-429 http://dx.doi.org/10.1016/j.jscs.2011.02.013

[8] Abbas J Attia, Salih H Kadhim, Falah H Hussein, Photocatalytic degradation of textile dyeing wastewater using titanium dioxide and zinc oxide, Journal of Chemistry, 5, 2, (2008) 219-223

[9] Dilek Gümüş, Feryal Akbal, Photocatalytic Degradation of Textile Dye and Wastewater, Water, Air, \& Soil Pollution, 216, 1, (2011) 117-124 http://dx.doi.org/10.1007/s11270-010-0520-z 